\title{
Inthalt.
}

Grite Abtheilung: Giufeifentes.

I. Bejent bes Metjobismus . . . . . . . . [1]

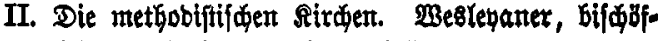

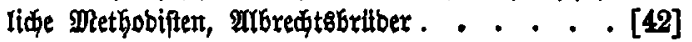

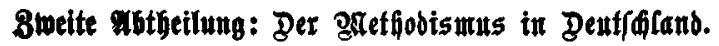

I. İmerifanifder Methobismut in Deutidilanb . 1

II. Neutefte Mirffamteit ber beutfdient Metģobiftent. 48

III. Rutálid . $\quad$. . . . . 61 



\section{Sirfte Olftheilung.}

Giuleiteubes. 
